\title{
Evaluation of Crop Production Practices by Farmers in Tshakhuma, Tshiombo and Rabali Areas in Limpopo Province of South Africa
}

\author{
Sylvester Mpandeli ${ }^{1,2}$ \\ ${ }^{1}$ University of Venda, School of Environmental Sciences, Department of Geography and Geo-Information \\ Sciences, Thohoyandou, South Africa \\ ${ }^{2}$ Water Research Commission of South Africa, South Africa \\ Correspondence: Sylvester Mpandeli, Water Research Commission, Private Bag X 03, Gezina, South Africa. \\ E-mail: sylvesterm@wrc.org.za
}

Received: April 25, 2014 Accepted: May 6, 2014 Online Published: July 15, 2014

doi:10.5539/jas.v6n8p10 URL: http://dx.doi.org/10.5539/jas.v6n8p10

\begin{abstract}
Limpopo Province is characterised by high climatic variability. This is a serious problem in Limpopo Province considering the fact that the province is in a semi-arid area with low, unreliable rainfall. The rainfall distribution pattern, for example, in the Vhembe district is characterised by wet and dry periods depending on the geographical location. In the Vhembe district high rainfall is usually experienced in the Tshakhuma and Levubu areas. Most of the rainfall received in the Vhembe district is in the form of thunderstorms and showers, and this makes rainfall in the district vary considerably. The impact of lower rainfall has negative effects on the agricultural sector, low rainfall resulting in decreases in agricultural activities, loss of livestock, shortage of drinking water, low yields and shortage of seeds for subsequent cultivation. For example, farmers in Rabali area are supposed to use hybrid seeds due to lack of sufficient irrigation water and also poor rainfall distribution compared to farmers in areas such as Tshakhuma and Tshiombo areas.
\end{abstract}

Keywords: agriculture sector, drought resistant seeds, coping strategies, crops planted

\section{Introduction}

Economic growth, as described in the Development Strategy of Limpopo Province, outlines agriculture as one of the three pillars of the economy (Motsoaledi, 2003). Agriculture is one of the most important components in economic growth in the province (Mufamadi, 2003). Such growth depends not only on good policy and strategic efforts for agriculture to serve as the cornerstone of the economy, but will require effective implementation of such plans and goals (Motsoaledi, 2003). There are four main reasons why agriculture is important to the future economic growth in Limpopo Province:

(a) Agriculture, being a major job creator in the province, is faced with a serious challenge to increase its opportunities of sustainable employment at which the provincial economy grows (Motsoaledi, 2003).

(b) The need to alleviate poverty, ensure food supply and increase economic growth calls for a more central role of the farming sector.

(c) Agriculture is traditionally an earner of foreign exchange.

(d) International evidence suggests that, even in more diversified middle-income economies, agricultural growth is instrumental in achieving higher overall rates of economic growth in the wider economy (UNCED, 1992).

The most widely used adaptation strategies in the Limpopo Province include drought resistant crop varieties, crop and livestock diversification, culling animals, food storage and early maturing crops (Babi et al., 2005). One interesting coping and adaptation strategy that farmers also use is forecasting, either local or traditional forecasting strategies that have evolved over time. Such strategies may provide farmers with useful information in order to optimize their agricultural practices (Scoones et al., 1996; Keys, 1999; Cullen et al., 2000; Nystron et al., 2000; de Menocal, 2001; Phillips et al., 2001; Scheffer et al., 2002; Patt \& Gwata, 2002; Berkhont, 2002; Folke et al., 2002; Podesta' et al., 2002; Adger et al., 2002; Adger, 2003; Ziervogel \& Calder, 2003; Berkes \& Jolly, 2004; Downing, 2004).

In South Africa one of the coping strategies most frequently used is for farmers to shift to crops that require less 
water such as sorghum (Annandale et al., 2002). The problem with such a strategy is that the majority of farmers in South Africa have very limited access to technology, market access and farm inputs (Vogel, 2000; Ziervogel, 2001; Ziervogel \& Downing, 2004; Ziervogel et al., 2005). The aims of this paper are: (a) To examine the types of seeds used by farmers in the Tshakhuma, Tshiombo and Rabali areas. (b) To assess the coping and adaptation strategies used by farmers in the Tshakhuma, Tshiombo and Rabali areas. (c) To evaluate the current crops planted by farmers in the Tshakhuma, Tshiombo and Rabali areas.

\section{Methodology}

Three study areas were selected for this research. The study areas are situated in the Vhembe district, which is situated approximately $184 \mathrm{~km}$ north of Polokwane. The research sites are located in rural areas with proximity to larger areas of commercial activity: for example, Tshiombo village is $35 \mathrm{~km}$ from Thohoyandou Central Business District (CBD), Tshakhuma village is $37 \mathrm{~km}$ away from Thohoyandou CBD and $40 \mathrm{~km}$ away from Makhado (Figure 1).

(a) Tshakhuma area is situated $28^{\circ} 30^{\prime}$, East longitude and $24^{\circ} 25^{\prime}$ ' South latitude $35 \mathrm{~km}$ West of Thohoyandou Central Business District. The following villages share boundaries with Tshakhuma village: Levubu, Elim and Lwamondo. These villages are situated at an altitude of $600 \mathrm{~m}$ above sea level.

(b) Rabali area is situated $30^{\circ} 30^{\prime}$ East longitude and $24^{\circ} 58^{\prime}$ 'South latitude, $25 \mathrm{~km}$ from Thohoyandou Central Business District and $15 \mathrm{~km}$ from Makhado (formerly known as Louis Trichardt). The following villages share boundaries with Rabali village: Raliphaswa, Dzanani, Mauluma and Ha-Matidza. These villages are situated at an altitude of between 600-700 $\mathrm{m}$ above sea level.

(c) The Tshiombo area is situated $30^{\circ} 50^{\prime}$ East Longitude and $22^{\circ} 79^{\prime}$ South Latitude, $35 \mathrm{~km}$ North of Thohoyandou Central Business District. The following villages share boundaries with Tshiombo: Tshandama, Makonde, Pile and Thengwe. These villages are situated at an altitude of $650 \mathrm{~m}$ above sea level.

\section{Map of the Study Area}
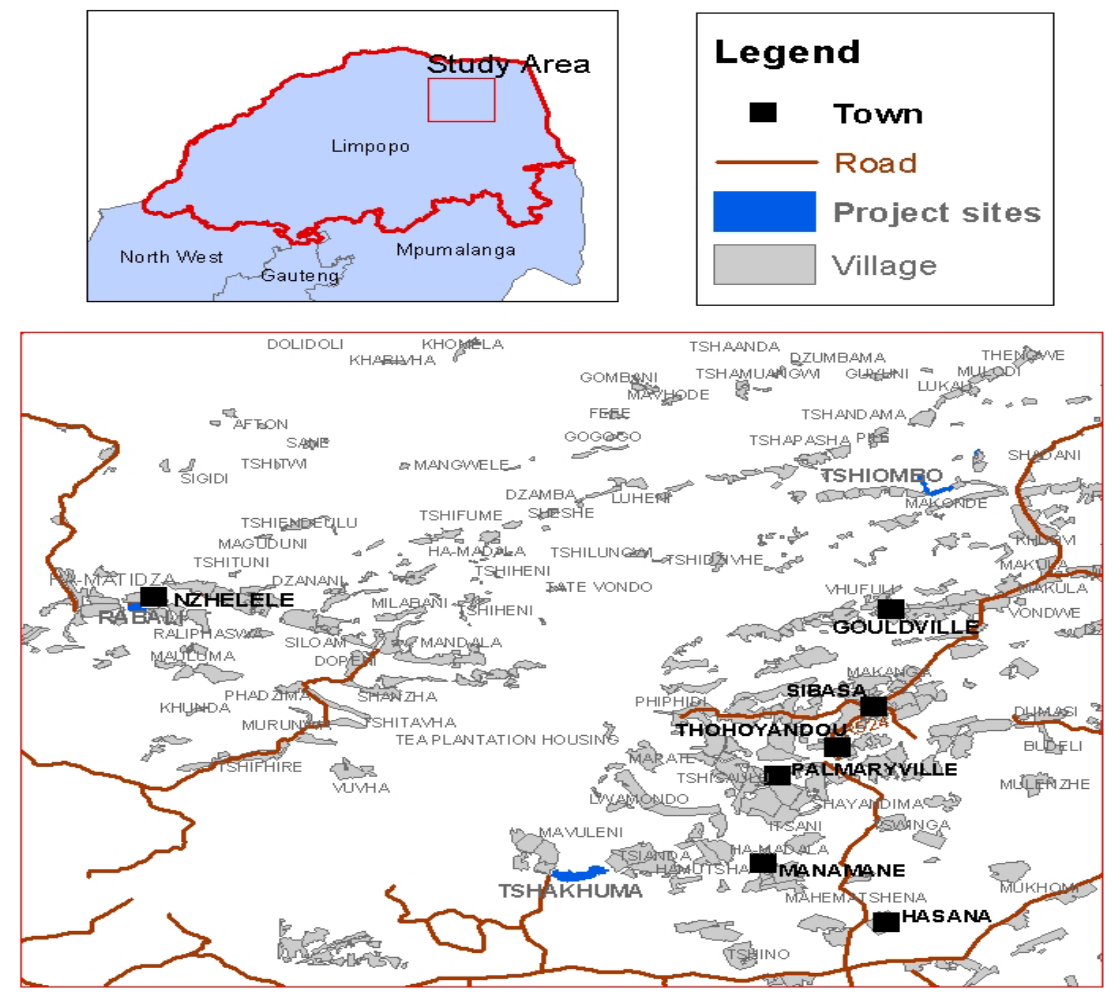

Figure 1. Map of Limpopo Province showing different villages in the Vhembe district (former Venda homeland) (ARC-ISCW, 2003) 
Pre-survey visit: A pre-survey visit was arranged within the selected areas with the tribal authorities of each area. The objectives of the pre-survey visit were: to meet the tribal authorities such as headman, chief and civil organisations of the selected area; to demonstrate the objective of the survey and the content of the intended questionnaires; to introduce the survey team to the tribal authorities and to seek permission to be able to work in each of the communities; to meet agricultural officials including district officials in Limpopo Provincial Department of Agriculture (LPDA) and officials involved in the community (for example, extension officers).

Data for this study was collected over a one-year period from the communities of Tshakhuma, Rabali and Tshiombo within the Vhembe district. The data were obtained in two different but consecutive phases. Two methods were employed: Formal survey and non-structured surveys. Household surveys were conducted during 2003/2004 seasons in three different villages in the Vhembe district (Tshakhuma, Rabali and Tshiombo). A total of 90 farmers were interviewed during the formal survey; they were chosen using random sampling techniques. It is important to note that 30 farmers were interviewed in each village (Tshakhuma, Rabali and Tshiombo). Methods used to achieve the aim included literature reviews, survey instruments, participatory rural appraisal and focus group with several farmers in the area, as well as stakeholder and key informant interviews.

\section{Results and Discussion}

Agriculture in Limpopo is not, however, only determined by rainfall and vegetation status. Other factors such as access to credit, markets, and farm inputs also can heighten the impacts of droughts. Agriculture is ranked third after the mining and tourism sectors in Limpopo Province (Ravele, 2003). Agriculture is an important sector for the South African economy for job creation, rural development, food security and foreign exchange (National Treasury Report, 2003). Current estimates indicate that primary agriculture, which refers to farm-level production, accounts for approximately 4\% of Gross Domestic Product (GDP) (Statistics South Africa, 1998).

The contribution of the agricultural sector is, however, more significant when the input and processing sectors are considered. The agricultural sector includes all activities relating to farming activities, supplies of inputs, processing and distribution functions that add value to farm products. Commercial farming plays a dominant role in the agricultural sector. Small subsistence and emergence farming, however, are increasingly becoming important because of their contribution to poverty reduction and job-creation in the rural areas (National Treasury Report, 2003).

Agriculture is undertaken by both men and women. Women engage in agricultural production processes such as planting, weeding, harvesting, threshing and gardening, as well as collecting firewood, preparing food and rearing children (Makhura, 1993; Mahapa, 2001).

\subsection{Types of Seeds Used in the Tshakhuma, Rabali and Tshiombo Areas}

Different types of seeds are being used in many parts of the Vhembe district. The majority of the farmers prefer to use hybrid seeds and some farmers mix hybrid seeds and the traditional recycled seeds. More than half of the farmers interviewed use hybrid seeds but these seeds are not drought-resistant (Figure 2a, 2b, 2c). At least 62\% of the farmers in the Tshakhuma area use hybrid seeds, while $78 \%$ of the farmers in the Rabali area also use hybrid seeds.

The majority of the farmers in the Rabali area stated that due to the fact that they were farming in a dry-land area where the climatic condition were always variable, they had no choice but to use hybrid seeds in order to obtain good production. In the Tshiombo area only $52 \%$ of the farmers use hybrid seeds. Less than $45 \%$ of the farmers in the Tshakhuma, Rabali and Tshiombo areas prefer to use both traditional and hybrid seeds together as part of risk-aversion strategies against periods of climate stress.

The fact that the majority of the farmers in the Tshakhuma, Rabali and Tshiombo areas prefer to use hybrid seeds is due to the following reasons:
(a) increased yield per hectare;
(b) drought-resistance; and
(c) resistance to diseases and pests. 

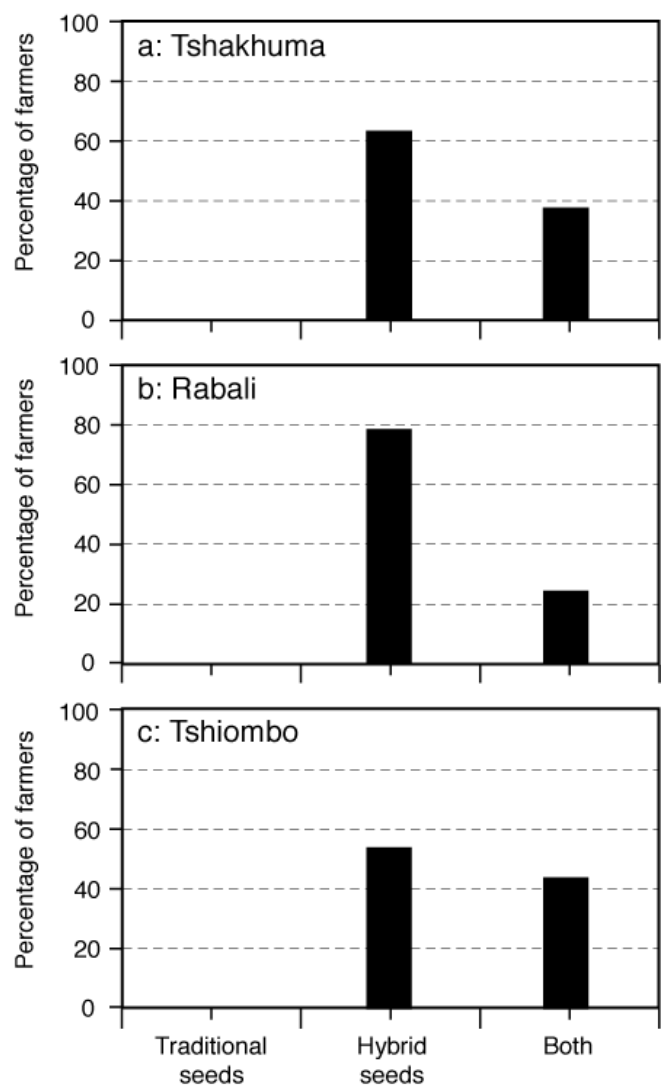

Figure 2. Types of seeds used in the Vhembe district. (a) Tshakhuma, (b) Rabali and (c) Tshiombo areas

Of all the farmers interviewed, only two percent of the farmers in the Tshiombo area preferred to use traditional seeds only. When some farmers were asked why they were no longer using traditional seeds, they indicated that traditional seeds alone are not producing good yields because they:

(i) harbour pests;

(ii) produce lower yields;

(iii) are less drought-tolerant; and

(iv) are easily attacked by diseases.

Tshakhuma and Rabali farmers are also no longer using traditional seeds. Having described different types of seeds used by farmers in the Tshakhuma, Rabali and Tshiombo areas, an assessment of the characteristics of crops planted in the Vhembe district is presented.

\subsection{Characteristics of Crops Planted in the Vhembe District}

Vhembe district is one of the high-potential agricultural areas of the province. Farmers in this district (including Tshakhuma, Rabali and Tshiombo areas) produce subtropical and tropical crops. In this district, agriculture is one of the key livelihood activities. In the Tshakhuma area, for example, $70 \%$ of the farmers in the area planted perennial crops such as avocado, followed by banana producers (18\%) and "others", including groundnuts, maize and cowpea.

Avocado and banana crops are usually grown in the Tshakhuma area favoured by good climatic and soil conditions (Figure 3a). The other reason for having a number of banana producers is because Levubu farmers, who are farming on the eastern side of Makhado, used to collaborate with Tshakhuma farmers. This helped Tshakhuma farmers to access banana seedlings easily. Less than eight percent of the farmers in the Tshakhuma area produce cabbages, and another four percent of the farmers produce seasonal crops such as onion, carrots, lettuce and cabbage.

The results from the field research for this thesis, in the Rabali and Tshiombo areas, indicate that the majority of the farmers in both areas produce seasonal crops such as maize, groundnuts and peas with a few producing 
avocados and cabbages. The majority of the farmers (90\%) interviewed in the Rabali area produce "other" crops including cowpea, sorghum and groundnuts (Figure $3 b$ ).

Farmers in the Rabali area have been trying to diversify their cropping system in order to increase production even though they are farming in a dry-land area. The majority of the farmers indicated that groundnuts and cowpea grow well in dry-land areas because these crops require less water compared to some other crops such as avocado and banana. Groundnuts and cowpea crops also conserve moisture by covering the soil surface (Annandale et al., 2002).
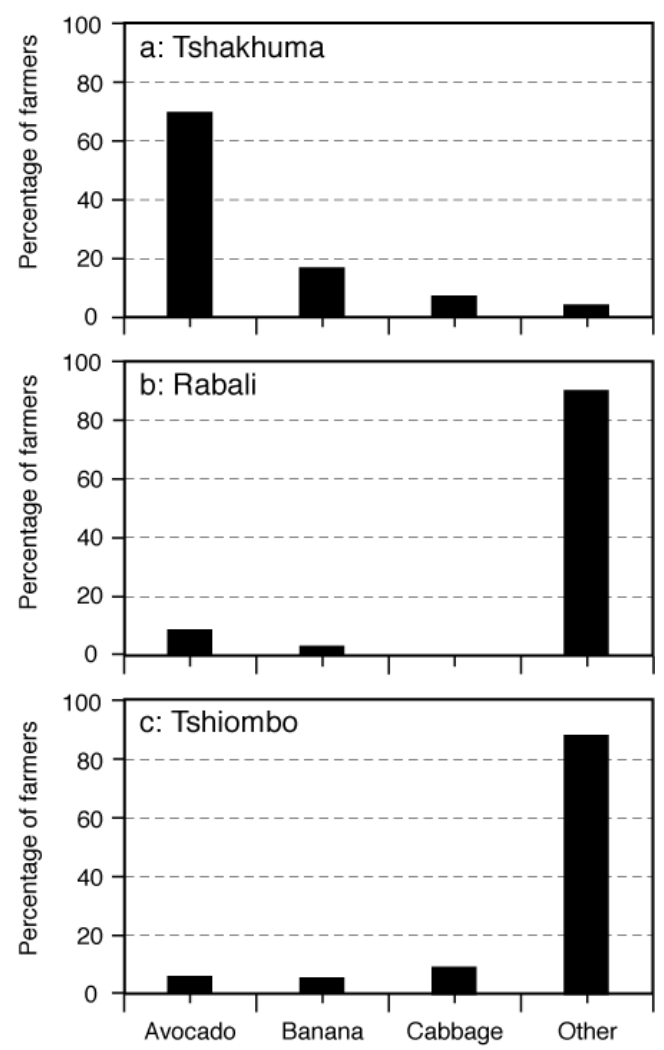

Figure 3. Types of crops available in the Vhembe district. (a) Tshakhuma, (b) Rabali and (c) Tshiombo areas

In the Tshiombo area less than $10 \%$ of the farmers plant banana, avocado and cabbage, while, $88 \%$ of the respondents plant "other" varieties of crops, such as sweet potatoes and tomatoes (Figure 3c). These types of farmers may not suffer high losses, unlike farmers who concentrate only on a monoculture system. During drought periods, these farmers should be able to have some production from different crops. As stated in the previous chapter, farmers who diversify their cropping system have a better chance of having a good net profit even during unfavourable weather/climatic conditions. 

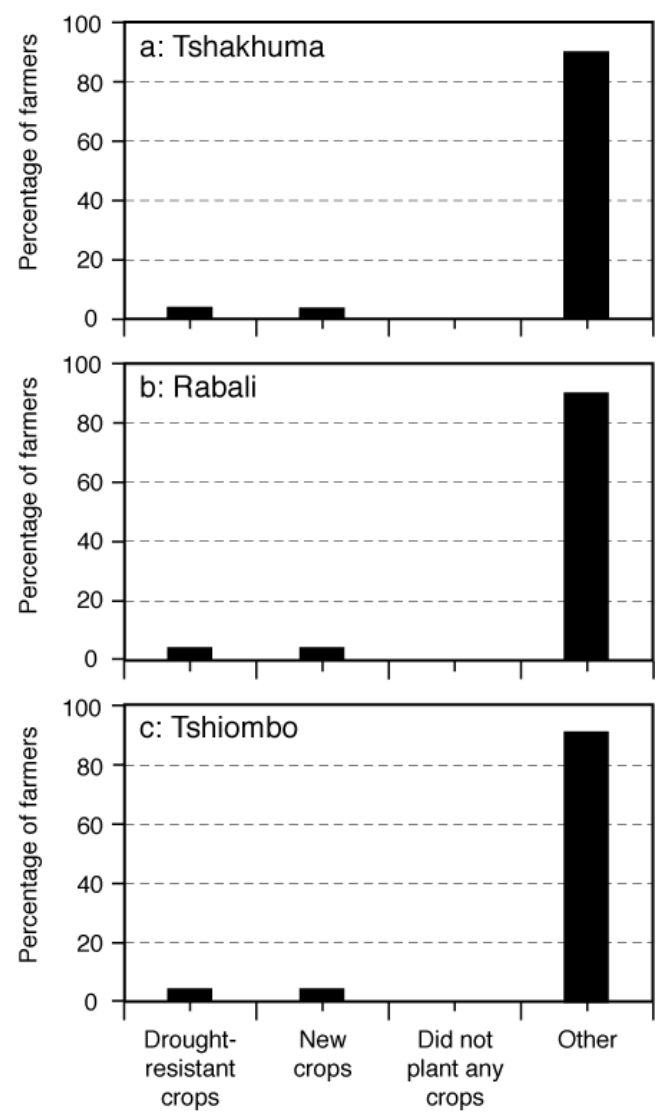

Figure 4. Crop planting strategies in the Vhembe district. (a)Tshakhuma, (b) Rabali and (c) Tshiombo areas

Only two percent of the farmers in the Tshakhuma area used drought- resistant crops such as groundnuts and sorghum (Figure 4a). The majority of farmers in the Tshakhuma area are horticultural crop producers (these farmers produce crops such as avocado, banana, litchis, guavas) and another two percent of the farmers use "new " crops, for example Morgan and Pioneer seed companies. Some farmers in the Tshakhuma area plant these crops not only for consumption but also for commercial purposes, even though these farmers do not currently have market access.

The results from the Rabali study indicate that only two percent of farmers interviewed are using drought-resistant crops, and another two percent of the farmers are using only new crops. The majority of the farmers in the Rabali area (90\%) have not changed planting patterns even though they practise farming under dry-land conditions (Figure 4b). It was observed that the majority of farmers in all the three study sites are still planting 'other' heat sensitive crops such as watermelons and sweet potatoes. This is one of the reasons why during drought periods the majority of the farmers suffer high losses of production, because only small numbers of farmers are using drought-resistant crops as part of their coping strategies or risk- aversion strategies.

The other reason why only small numbers of farmers are using drought-tolerant crops in all the three study sites is due to the following:

(i) the high price of the seeds, and

(ii) the lack of transport because most seed campanies are far located from the area.

These farmers should use more drought-tolerant crop varieties due to the fact that Rabali area is a dry-land area, and there is less reliable rainfall, unlike farmers in the Tshakhuma area who are farming in a more favourable conditions.

Farmers in the Tshiombo area do not use drought-resistant crops but they have better crop diversification strategies in their farming business. These farmers change crop varieties most of the time, but the number of the farmers using drought-tolerant crops is still very low (Figure 4c). The problem is that if the majority of farmers from the three different areas do not use drought-resistant crops, then there is danger of experiencing low production, especially during drought periods. Farmers indicated that this does not mean they do not want to use 
drought-resistant crops but lack of capital and transport are serious impediments. This might result in hunger and starvation, especially in those households that depend totally on farming for a livelihood.

Drought-tolerant crops should ideally be used by the majority of farmers in the Vhembe district because of low water availability in the dams, unreliable rainfall and drought problems. All the farmers in the three study sites had similar results for the crops planted in the study areas. On close examination, however, such as in Tshakhuma and Tshiombo, it would seem that farmers in those areas do not experience water shortages to the same extent as those in the Rabali area.

Rabali farmers are farming in a dry-land area, so different coping strategies are required in order to have good agricultural production. Tshiombo farmers are farming in an irrigation area but farmers have other problems, for example, inability to access inputs such as fertilizers and lack of capital. The other problem in the Tshiombo area is that there are problems of access to water and 'politics' in terms of water allocation. Tshakhuma farmers are farming in micro-climatic zones but they are losing agricultural production because of diseases, pests and theft problems.

\section{Conclusions and Recommendations}

Limpopo Province offers a range of opportunities as well as challenges for farmers. The province is one of the poorest provinces, characterized by high unemployment, and a lack of access to a range of resources that all frustrate farmers' ability to secure livelihoods. Limpopo Province is characterised by high climatic variability, for example, poor rainfall distribution. The rainfall distribution pattern, for example, in the Vhembe district is characterised by wet and dry periods. When lower rainfall periods occur, negative effects on the agricultural sector usually result including: (a) Decreases in agricultural activities, (b) Loss of livestock, (c) Shortage of drinking water, (d) Low yields and shortage of seeds for subsequent cultivation, and reduced vegetation potential for grazing livestock. Results from the survey show that Vhembe district is, however, also characterised by some high-potential agricultural areas. Details include: (i) Results indicate that farmers in the Vhembe district (including Tshakhuma, Rabali and Tshiombo areas) produce subtropical and tropical crops. (ii) In the Tshakhuma area, for example, $70 \%$ of the farmers in the area planted perennial crops such as avocado, followed by banana producers (18\%) and "others", including groundnuts, maize and cowpea. (iii) In the Rabali and Tshiombo areas, results from the survey show that the majority of the farmers in both areas produce seasonal crops such as maize, groundnuts and peas with a few producing avocados and cabbage. (iv) The results also show that less than (20\%) of the farmers in the Tshakhuma, Rabali and Tshiombo areas are using drought-resistant seeds.

A number of recommendations emerge from this paper that could be considered in the Limpopo Province and may require further research: (a) Farmers should be encouraged and enabled to use crop diversification as a climate-risk management strategy especially in area such as Rabali due to high climatic variability and change. This will help farmers to reduce risk during uncertain periods. (b) Local farmers should be encouraged to use drought-resistant cultivars during drought periods. (c) As this paper has also shown, a 'one-risk reduction approach' to the various stresses faced in the Limpopo Province will therefore not fit all. Tshakhuma, Rabali and Tshiombo areas have varying farming practices and varying needs in terms of agricultural production. (d) It has been highlighted in this paper an effective interventions to better manage agricultural risks especially in area such as Rabali are to be designed and implemented with farmers in Limpopo Province.

\section{References}

Adger, W. N. (2003). Does global environmental change cause vulnerability to disaster? In M. Pelling (Eds.), Natural Disasters and Development in a Globalization World (Vol. 7, No. 8, pp. 56-69). Routledge: London.

Adger, W. N., Huq, S., Brown, K., Conway, D., \& Hulme, M. (2002). Adaptation to climate change: Setting the Agenda for Development Policy and Research. Progress in Development Studies, 3(3), 179-195. http://dx.doi.org/10.1191/1464993403ps060oa

Agricultural Research Council-Institute for Soil Climate Water (ARC-ISCW). (2003). The Agrometeorological climate databank. Instruments and sensors used in the Agrometeorological station network. Technical report presented to the ARC management.

Annandale, J. G., Jovanovic, N. Z., Mpandeli N. S., Lobit, P., \& du Sautoy, N. (2002). Two Dimensional Energy Interception and Water Balance Model for Hedgerow Tree Crops. Paper presented at Southern African Society of Horticultural Sciences congress at Cedara, Kwazulu Natal, 15-17 January 2002.

Babi, D. D. (2005). Assessing the vulnerability of FADAMA (flood plain) agriculture to climate variability and change. A case study of semi-arid Northern Nigeria. 
Berkes, F., \& Jolly, D. (2002). Adapting to climate change: Social-ecological resilience in a Canadian Western Arctic community. Conservation Ecology, 5(2), 514-532.

Berkhout, F. (2002). A Conceptual Framework for Adaptive Capacity. ADAPT Project Note, SPRU. University of Sussex, Brighton, UK.

Cullen, H. M., de Menocal, P. B., Hemming, S., Hemming, G., Brown, F. H., Gulderson, T., \& Siroko, F. (2000). Climate change and the collapse of the Akkadian empire: Evidence from the deep-sea. Geology, 28(4), 379-382. http://dx.doi.org/10.1130/0091-7613(2000)28\%3C379:CCATCO\%3E2.0.CO;2

De Menocal, P. B. (2001). Cultural responses to climate change during the late Holocene. Science, 292, 667-673. http://dx.doi.org/10.1126/science.1059827

Downing, T. E. (2004). Vulnerability in NAPA Assessments. Guidance, examples and team exercises for developing rapid, participatory vulnerability assessments in National Adaptation Programmes of Action.

Folke, C., Carpenter, S., Elmqvist, T., Gunderson, L., Holling, C., Walker, B., ... Svedin, U. (2002). Resilience and Sustainable Development: Building Adaptive Capacity in a World of Transformations, Report 2002:1. Swedish Environmental Advisory Council, Stockholm.

Keys, D. (1999). Catstrophe: An investigation into the Origins of the Modern World. Arrow Books. London.

Mahapa, S. F. (2001). Rural Women, Food insecurity and survival strategies: The Babina-Chuene Women's Multi-Purpose project in Bochum (Northern Province). Unpublised M. A. dissertation, Pretoria, University of Pretoria.

Makhura, T. J. (1993). The Bagamana Polity in the North West Transvaal and the South African Republic. Journal of Agricultural Economics, 1836-1986. Mmabatho: University of Bophuthatswana.

Motsoaledi, P. A. (2003). Supplement to Nufarmer \& African Entrepreneur (March 8, 2003, Vol. 2). Press release.

Mufamadi. (2003). Assistant director, personal communication.

National Treasury Report. (2003). Department of Treasury. Treasury Report (pp. 95-117).

Nystrom, M., Folke, C., \& Moberg, F. (2000). Coral reef disturbance and resilience in a human-dominated $\begin{array}{llllll}\text { environment. Trends in Ecology \& } & \text { Evolution, } & 15(10), 417 .\end{array}$ http://dx.doi.org/10.1016/S0169-5347(00)01948-0

Patt, A., \& Gwata, C. (2002). Effective seasonal climate forecast applications: examining constraints for subsistence farmers in Zimbabwe. Global Environmental Change, 12, 185-195. http://dx.doi.org/10.1016/S0959-3780(02)00013-4

Phillips, J. G., Makaudze, E., \& Unganai, L. (2001). Current and potential use of climate forecasts for resource-poor farmers in Zimbabwe. In C. Rosenzweig (Ed.), Impacts of El Nino and climate variability in agriculture (American Society of Agronomy Special Publication No. 63, pp. 87-100). Madison, Wisconsin.

Podesta, G., Letson, D., Messina, C., Royce, F., Ferrera, R. A., Jones, J. W., ... O’Brien., J. J. (2002). Use of ENSO-related climate information in agricultural decision making in Argentina: a pilot experience. Agricultural Systems, 74, 371-392. http://dx.doi.org/10.1016/S0308-521X(02)00046-X

Ravele. (2003). Agricultural extension officer, personal communication.

Scoones, I. C., Chibudu, S., Chikura, P., Jeranyama, D., Machaka, W., Machanja, B., ... Zirereza, B. (1996). Hazards and opportunities: farming livelihoods in dryland Africa: lessons from Zimbabwe. London: Zed books, Ltd.

Statistics South Africa. (1998). Preliminary estimates of the Size of the Population of South Africa. Census, 1996.

UNCED. (1992). Building the foundation for sustainable development in South Africa. National report to the United Nations Conference on Environment and Development (UNCED) to be held in Rio de Janeiro, June, 54.

Vogel, C. (2000). Usable science: an assessment of long-term seasonal forecasts among farmers in rural areas of $\begin{array}{llll}\text { South Africa. South African Geographical Journal, 82, 107-116. } & \text {. }\end{array}$ http://dx.doi.org/10.1080/03736245.2000.9713700

Ziervogel, G. (2001). Global science, local problems: seasonal climate forecast use in a Basotho village, 
Southern Africa. Paper prepared for presentation at the Open Meeting of the Human Dimensions of Global Environmental Change Research Community, Rio de Janeiro, October, 6-8.

Ziervogel, G., \& Calder, R. (2003). Climate variability and rural livelihoods: assessing the impact of seasonal climate forecasts in Lesotho. Area, Agricultural Systems, 35, 403-418.

Ziervogel, G., \& Downing, T. E. (2004). Stakeholder networks: improving seasonal climate forecasts. Climatic Change, 65, 73-101. http://dx.doi.org/10.1023/B:CLIM.0000037492.18679.9e

\section{Copyrights}

Copyright for this article is retained by the author(s), with first publication rights granted to the journal.

This is an open-access article distributed under the terms and conditions of the Creative Commons Attribution license (http://creativecommons.org/licenses/by/3.0/). 